\title{
Exploration on the Enterprise Model of Intramural Practical Training of Marketing in Technician College
}

\author{
Ting Qin \\ Zhuhai Technician College \\ Zhuhai, China 519000
}

\author{
Songchun Wang* \\ Beijing Institute of Technology, Zhuhai \\ Zhuhai, China 519088 \\ *Corresponding Author
}

\begin{abstract}
The practical training mode of the enterprises practically trained in school is the inevitable choice of the practical teaching of marketing major that cannot separate the real enterprise environment. Meanwhile, it is also an important carrier for the integrated curriculum reform of marketing major and a powerful supplement to the existing practical training mode. Through such mode, the goal of training high-skilled talents can be realized with more targeted, and the theoretical teaching of marketing courses can be directly combined with the real operation of enterprises to achieve the "classroom + enterprise" teaching form.
\end{abstract}

Keywords—practical training enterprises; brand image stores; technician colleges; skilled talents

\section{INTRODUCTION}

With the deepening penetration of the spirit of workmanship in large countries into all sectors of society, the improvement of the quality of technician's education has been paid more and more attention by the educational circles. It is also an indisputable fact that the graduates of technician colleges are increasingly highly concerned and welcomed by employers. At the same time, the Ministry of Human Resources and Social Security has abolished more than 300 professional qualification appraisal examinations from 2015 to 2017, including marketing teachers and customer service teachers, thus forming a more open employment environment. Marketing majors are facing the challenges of the times, on the one hand, the demand for marketing posts has been increasing year by year, and on the other hand, the employment export of marketing graduates from technician colleges is still not accurate enough. The main reason for the imbalance between supply and demand is that students lack practical experience in school learning, and the practical training in school is far from the actual development of enterprises. In consideration of the factors such as the safety of students who go out for practice, it is the most effective way to restore the demand of enterprises to simulate the real enterprise environment in school.

Exploring how to create a model of intramural practical training is a key topic for marketing major to accelerate the pace of development and deliver more excellent skilled talents to local areas. In recent years, there have been various explorations on the reform of practical training of marketing major and each has its own merits. By contrast, it is considered that the practical training enterprise model is the most effective one according to the actual situation of our school.

\section{ThE ESTABLISHMENT OF PRACTICAL TRAINING ENTERPRISES IS THE INEVITABLE CHOICE OF INTRAMURAL PRACTICAL TRAINING}

\section{A. The Teaching Practicality of Marketing Major Is Inseparable from the Real Enterprise Environment}

Most of the courses in marketing major have strong practicality such as marketing technology, business negotiation, marketing planning, brand management and etc. Without the real competitive environment, the teaching effect will be significantly reduced. As a non-engineering technician college discipline, how to achieve the goal of training skilled personnel with practical ability is the first issue to be discussed. However, the practical ability is obviously insufficient only by teaching in the class, even if the understanding of theoretical knowledge by using abundant case teaching, which is not as effective as giving students the experience of "real gun and bullets". In the past, we only consider to let students practice in enterprises, which is difficult to arrange the operation reasonably on the one hand, and which is easy to cause the phenomenon that the practice is not in line with the goal of teaching content and personnel training on the other hand. Through the practical training enterprises, the practical training activities can not only truly show the real business environment, but also systematically achieve the consolidation and application of learning, thus improving the teaching efficiency.

\section{B. The Carrier That the Integrated Curriculum Reform of Marketing Major Needs to Rely on}

The ultimate goal of the integrated curriculum reform is to realize students' active acquisition of skills from the process of hands-on, and then transform them into their own knowledge structure. Compared with traditional teaching, it completely subverts the idea that knowledge comes from teachers Therefore, how to create hands-on projects in school is the key to solve the integrated curriculum reform. Practical training enterprises can not only meet the goal of personnel training, but also enable students to participate. Meanwhile, dynamic 
projects can more stimulate students 'learning enthusiasm, which is the best choice to assist the integrated curriculum reform.

\section{A Powerful Supplement to the Existing Practical Training Modes}

At present, there are two most common practical training modes for marketing majors: one is to let students practice in enterprises. Although this way can help students deeply get in touch with enterprises and understand the process of operating management and marketing operation of enterprises, its biggest disadvantage is that it is difficult to arrange. The other is intramural simulated practical training, such as using the practical training room as a simulated market, where students act as trading parties, imitate the transaction process, and train students' negotiation skills; analyzing the virtual companies, writing market analysis reports and marketing planning, etc., which is the most cost-effective way and improves the students' operating practical ability to a certain extent. However, the virtual environment cannot always make students feel the pressure and the temptation of interests brought by the real market, and also cannot let students really integrate into the market environment. Therefore, the practical training effect cannot achieve the expectations.

However, practical training enterprises can overcome these problems, such as when enterprises have special needs (largescale promotional activities, trade fair, expositions, etc.): practical training enterprises can bring convenience to enterprises in time and solve the problem of enterprises' demand for temporary labor forces. At the same time, students can feel the feedback from the market and their own work results in real time in the process of participation, which is conducive to improving students' learning enthusiasm.

\section{The Practical Training Enterprises Have Adapted to the Training Goals of High-skilled Personnel of Marketing Major}

The training goals of marketing professionals in technician colleges can be divided into two categories:
1)Marketing management talents (such as store manager and marketing manager): On the one hand, the establishment of image stores of practical training enterprises can adopt the needs of the development of chain stores for managerial personnel and solve the employment problem of students; on the other hand, it can also cultivate students' ability to manage stores and lay a foundation for future self-employment.

2)The marketing talents of enterprise first-line product (such as sales representatives, promotion specialists, etc.): Practical training enterprises encourage and require students (it can be regarded as the practical training results) to open up markets for them by acting as sales agents of products of some enterprises. Through sales experience, students can taste the joy of success and enhance their self-confidence and interest in learning. At the same time, the cruelty of competition and the hardship of creating performances can also exercise students' psychological endurance capacity, which urges them to sum up the experience from failure, turns passive learning into active learning, and improve the interestingness of learning.

\section{Design OF Operating MOdE OF PracticAl Training ENTERPRISES}

\section{A. Organizational Structure of Practical Training Enterprises}

The practical training enterprise is a kind of organizational form which is set up by marketing major, simulates the modern enterprise management system, guided by professional teachers, managed by students independently, and launches the practical training activities with the goal of directed training of skilled talents of marketing major. This form directly combines the classroom teaching of marketing major courses with the actual operation of enterprises, and implements the "classroom + enterprise" teaching mode. The organizational structure is shown in "Fig. 1".

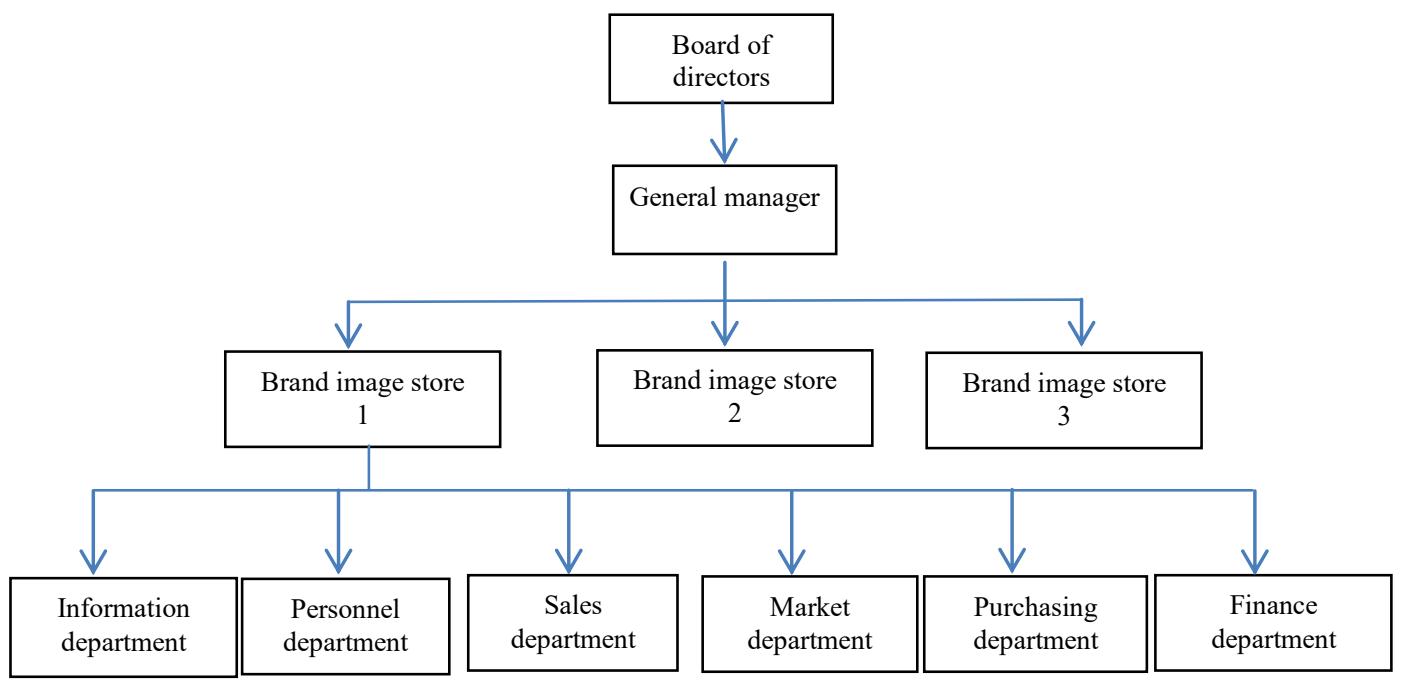

Fig. 1. Organizational chart of practical training enterprises. 
In the organizational structure of the practical training enterprise, the division of principals at all levels is shown in "Fig. 2".

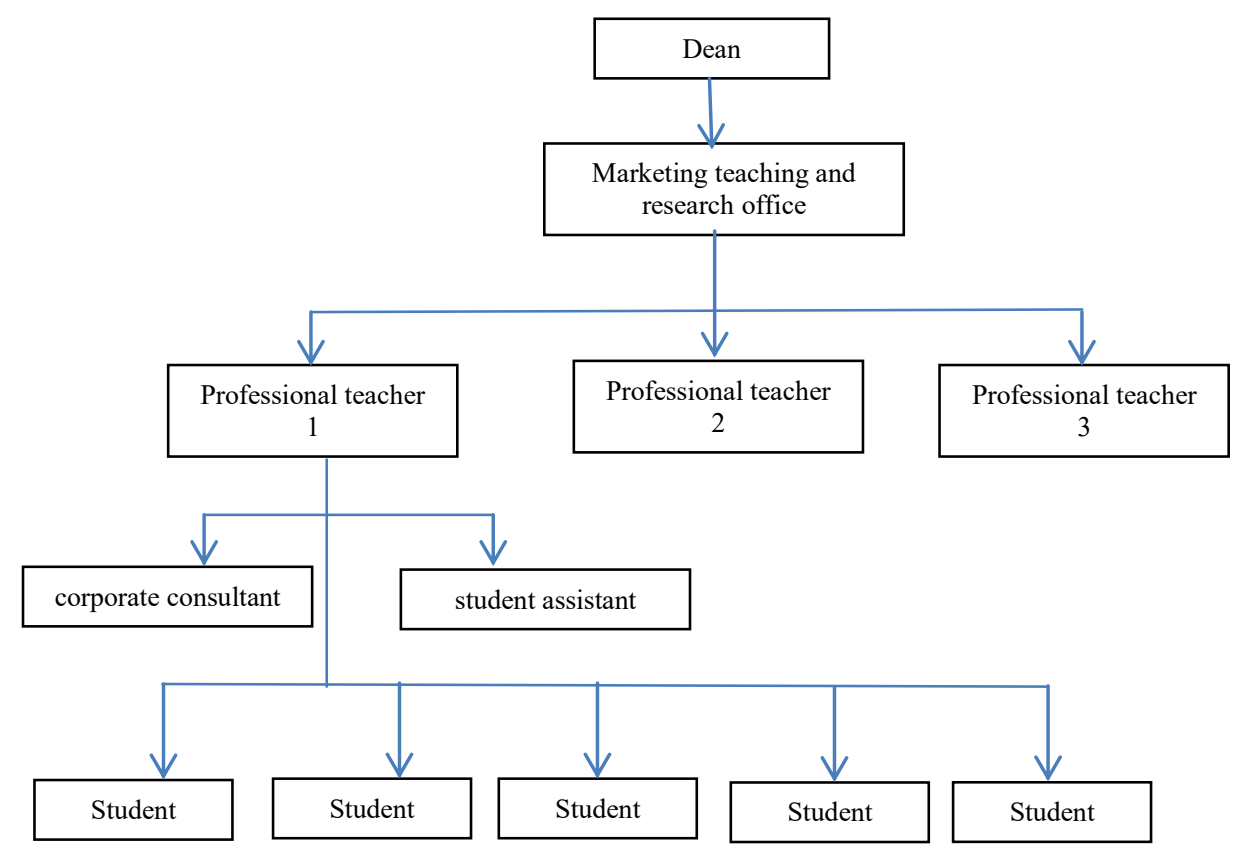

Fig. 2. The constitutive structure of the practical training enterprise personnel.

\section{Management System of Practical Training Enterprises}

The head of the department in which the marketing major is located is the principal person who is in charge of the practical training enterprise. The dean will be responsible for coordinating the problems between the enterprises and the college, the leaders and other relevant departments. Meanwhile, the dean will be able to provide help when the enterprises need the school to show up, attend some important occasions if necessary, appear as the representative of the guarantor when guaranty is needed, and also exercise the right to manage the assets of the college on behalf of the school that is the main investor, so the dean of the department is suitable for the position of chairman of the enterprise.

Marketing teaching and research office is the actual operating party of the enterprises. All business activities of the enterprise will be completed by the teaching and research office that is responsible for the overall planning and arrangement of the whole operation, as well as coordination with teachers and students. Therefore, the marketing teaching and research office is suitable for the position of general manager of the enterprise.

The specific business affairs of each brand image store are planned by professional teachers as a whole. Professional teachers and corporate consultants work together to complete business activities, the daily work of image stores is mainly completed by student assistants, while teachers mainly play a guiding role. In accordance with the department setting modes of enterprises, image stores are composed of information department, personnel department, finance department, market department, purchasing department, marketing planning department and other permanent organizations whose members are composed of students.

\section{Operation Pattern of Practical Training Enterprises}

1) General thoughts of operation: The practical training enterprise mainly serves as the sales agency of the brand. The enterprises and the cooperative enterprises sign the agency agreement, which the former is responsible for the product sales business of the latter in the school and the areas near the school, and then the practical training enterprise earns the sales fee or the price difference. However, it is difficult for them to exercise the right of sales agency because the practical training enterprises are in the initial stage, and publicity needs to be more done in the earlier stage.

2) Modes of operation of funds: When preparing for the construction of the practical training enterprise, the school arranges the practical training venues, and at the same time allocates a certain amount of start-up funds in the student practical training funds at one time for the establishment of the enterprise venues, decoration and purchase of necessary equipment. If it is a school-enterprise cooperative project, it can be purchased by the cooperative enterprises. In addition, other operating funds adopt the form of simulated joint-stock system,which are raised among students according to needs, mainly for the turnover of company circulating fund. Students who participate in the practical training can withdraw a certain amount of subsidies from the profits of enterprises, instead of the expenditure from the practical training funds.

The finance department of the practical training enterprises is responsible for the operation of all funds and manages them 
according to the company's financial management system. Schools only need to give some financial support at the beginning of the construction of practical training enterprises and the follow-up operation of the practical training enterprises is completely enterprise-based and market-oriented. The practical training expenditure of marketing students will be borne by the practical training enterprises, and the school will no longer invest in the practical training cost, thus saving the cost of running the school.

If the practical training enterprises are profitable, whose use is divided into two parts: one part is a certain proportion of retained interest, and as the company's further development funds; the other part is used to compensate students' community activities, which achieves the purpose of "cultivating profession through practical training" and no longer need school expenditure. Remaining profits after the above two parts of expenditure are used as dividends for student shareholders.

3) Practical training executive process: Assuming that a class takes part in practical training every two weeks, and practical training management implements the brand project management system, a practical training group is responsible for a brand project: each group members have the opportunity to contact the links of store sales and outside sales. If there is a purchasing task, the personnel of the brand will participate in the purchasing process, and the final results will be determined by sales volume and attitude of practical training and others.

For example: a class of 50 students to participate in the practical training, and practical training enterprises totally consign five brands, there are five brand project groups with each group of 10 students, and then each group draws out a student who stands image shops every day as the promotional staff of the brand in the store, each student can turn to the shop to be on duty for two weeks. The rest of the students set work tasks according to the practical training contents such as sales skills practical training, which they can take the brand products out for sale, and market research practical training, which they can contact the brand enterprises. The research activities that the company is willing to carry out are launched and market research activities made by enterprises are well assisted. Meanwhile, the research results for the enterprises are provided and the basis for the enterprise decision-making is also provided. For example, the practical training of marketing planning, which the marketing planning schemes can be made according to the research conclusions of the market condition of brand enterprise, etc.

\section{The OUtstanding Role of Practical Training} ENTERPRISES

\section{A. It Is Conducive to a High Degree Matching Between Intramural Practical Training and Personnel Training Targets}

Professional training functions can be designed according to talent training targets and curriculum settings by using practical training enterprises as training bases, and experienced teachers for practical guidance will be dispatched, and professional practical training places will be provided for some students majoring in marketing according to local conditions. Meanwhile, practical training teaching plans will be drew up and the practical training enterprises should arrange students to go to relevant enterprises and corporate image stores for practical training. Students can participate in the practical training of image store manager, purchaser, cashier, salesman, etc.

In addition, the practical training enterprises can also incorporate the units cooperating with the training enterprises into the bases of various courses for students, which provides them with on-the-job training, reduces teaching costs, organizes students to take part in the enterprise's activities of commodity promotion and market survey during holidays, etc. Through the mode of practical training enterprises, we strive to close the distance between schools and society, schools and enterprises, so that students can accumulate work experience on campus and quickly adapt to the needs of enterprises after graduation.

\section{B. It Is Conducive to Promoting Intra-industry Exchanges, Promotion and Cooperation}

A platform for communication, exchange and cooperation for cooperative enterprises can be provided through practical training enterprises. The Marketing Elite Forum is sponsored by the Marketing Association, and different cooperative enterprises regularly organize marketing hot spot seminars, lectures and other activities. It is more conducive to exploring the new model of seamless connection between technician education and industry and trade by using the platform of practical training enterprises in schools.

\section{It Is Conducive to Maintaining a Stable and Developmental Relationship with Enterprises}

On the one hand, cooperative enterprises can make clear the needs of enterprises for talents through cooperative image stores, and marketing major can adjust the personnel training plan dynamically and intuitively through feedback from image stores to establish a long-term interactive personnel training mode of engineering talents between schools and enterprises; on the other hand, a window for external contact is established, the association strength between school and enterprises is strengthened, and the "production, education and research" communication and cooperation between schools and industries, enterprises is also strengthened through the practical training enterprises' external commodity procurement and agency business activities and organizing students to use holidays to carry out commodity promotion, market research and other training activities in off-campus enterprises. The mode of practical training enterprises enables enterprises to better understand professional construction and students' situation, which also creates a good opportunity for marketing teachers to get close to society, enter enterprises and gain practical experience, and enhances the possibility of establishing stable long-term cooperative relationship with enterprises. 


\section{Achieving Targeted Poverty Alleviation}

Professional skill training is an important part of targeted poverty alleviation. As an on-campus practical training enterprise, besides the training time of students in this major, it can cultivate students' labor concept by the form of recruiting student salesmen of different majors and organizing students to take part in the practical training activities during after-school time or holidays, which provides a way for students to exercise their marketing ability in spare time, enables students to obtain certain income or internship subsidy through these activities, and gives poor students the opportunity to improve their professional skills while studying on a work-study basis.

\section{E. Promoting the Improvement of Teachers' Social Practical Ability}

Marketing major is a system with strong practicality and timeliness. With the development of the times, the pattern of manifestation of knowledge is updated rapidly, which puts forward a high demand for professional teachers' market acuity. Practical training enterprise model can provide professional teachers with a channel to obtain the latest market information. In the process of running brand image stores together with enterprise consultants, they can learn new marketing, new sales, new technologies and other knowledge of enterprises, which improve their professional level, and complete the work mission of teachers that is constantly charging and renewing knowledge system.

\section{INNOVATIVE VALUE OF PRACTICAL TRAINING ENTERPRISES}

\section{A. Spontaneously Creating Training Bases in Schools to Achieve a "Win-win" Form of School-enterprise Cooperation}

Compared with the traditional practical supermarket and single training company, such practical training enterprise model creates a training platform, which can accommodate cooperative projects of multiple enterprises at the same time. It exists in the form of brand image stores, and can realize the situation of "win-win situation" between the school and many enterprises in a training form.

At the same time, a certain competitive mechanism is introduced, which creates a local competitive market among project teams, increases students' real social work experience, and makes the quality of graduates more in line with the requirements of enterprises.

\section{B. Solving the Problem of Difficult Practical Training Expenditures and Realizing the Growth of Students in Practical Training with Real Operating Income}

From the perspective of rational and efficient use of educational resources, such practical training enterprise model shares a part of the cost of running a school, and also maximum reduces the risk of opening a company in school and increases the probability of success. Although the model of practical training company is not perfect, it is the most tolerant one, which all kinds of new training models can be contained in it and complement one another. The innovation of practical training model based on practical training enterprises can make the model of practical training more improved continuously.

\section{CONCLUSION}

To sum up, the establishment of marketing practical training enterprises is a better form for students majoring in marketing to carry out practical training, which is conducive to the realization of the goal of talent cultivation. The "teaching site is enterprise site" training mode is implemented according to local conditions, which makes the combination of professional theory teaching and business operation and practice and the combination of teaching and labor. Therefore, students' enthusiasm and initiative in learning are fully mobilized, exploit the school-running characteristics of technician education, and achieve the goal of training highlevel skilled talents.

\section{REFERENCES}

[1] Zhang Yunling. Reflections on the Innovation of Marketing Practical Teaching of Higher Vocational and Technical Colleges [J]. Science, Technology and Economy Guide, 2016 (31): 141. (in Chinese)

[2] Wu Fangyong. Exploration and Analysis on Innovation of Marketing Practical Teaching System of Higher Vocational and Technical Colleges [J]. Modern Economic Information, 2016 (01): 406 + 408. (in Chinese)

[3] Huang Qiao. Discussion on the Construction of Intramural Training Base for Marketing Major of Higher Vocational and Technical Colleges [J]. Enterprise technology development, 2011 (11): 206-209. (in Chinese)

[4] Hu Fang. Analysis onTraining Mode of High-end Skilled Professionals in Business Management Major of Higher Vocational and Technical Colleges [J]. Journal of Huangshan University, 2013 (1): 88-90. (in Chinese)

[5] Liu Yong. Exploring the Construction Mode of Off-campus Training Base with Enterprise Campus as the Main Body [J]. China Higher Education, 2010 (9:47-48). (in Chinese)

[6] Chen Min, Feng Weixi. Construction and Research of Learning Situations under the Cooperation of Colleges[J]. Journal of Nurses'Further Education, March 2010, 25: 209. (in Chinese)

[7] Zhou Xiuhua, Zhang Jing. Critical Disease Nursing [M]. Beijing: People's Health Publishing House, 2005. (in Chinese)

[8] Zhang Shaoyu. Construction and Implementation of Work-study Combination Training Program for Nursing Major [J]. Journal of Nursing, 2011, 26 (6): 72. (in Chinese) 